Web Jurnal:

http://ejournal.kemenperin.go.id/jli

\title{
Pemanfaatan pati tapioka dan kitosan dalam pembuatan plastik biodegradable dengan penambahan gliserol sebagai plasticizer
}

\section{Utilization of tapioca starch and chitosan in production of biodegradable plastic with the addition of glycerol as plasticizer}

\author{
Fadlan Hidayat*1, Syaubari ${ }^{2}$, dan Reza Salima ${ }^{3}$ \\ 1 Program Studi Teknologi Pangan, Fakultas Teknologi Pertanian, Universitas Serambi Mekkah \\ Jln. Imum Lueng Bata Desa Batoh, Banda Aceh, Indonesia \\ 2 Jurusan Teknik Kimia, Fakultas Teknik, Universitas Syiah Kuala, \\ Jln. Tgk. Syech Abdulrauf No. 7 Darussalam, Banda Aceh, Indonesia \\ Program Studi Pengelolaan Perkebunan, Politeknik Indonesia Venezuela, \\ Jln. Bandara Sultan Iskandar Muda, Ingin Jaya, Aceh Besar, Indonesia \\ * e-mail: fadlanhidayat@serambimekkah.ac.id
}

\begin{tabular}{l}
\hline INFO ARTIKEL \\
\hline Sejarah artikel: \\
Diterima: \\
19 Februari 2020 \\
Direvisi: \\
6 Juni 2020 \\
Diterbitkan: \\
29 Juni 2020
\end{tabular}

\section{Kata kunci:}

pati tapioka;

kitosan;

plasticizer;

plastik biodegradable

\section{Keywords:}

tapioca starch;

chitosan;

plasticizer;

biodegradable plastic

\begin{abstract}
ABSTRAK
Tepung pati sering disebut dengan nama tepung tapioka dihasilkan dari ektrak umbi singkong. Pati tapioka dapat dimanfaatkan sebagai bahan utama dalam pembuatan plastik biodegradable. Tujuan penelitian untuk membuat plastik biodegradable dari pati tapioka dan kitosan dengan menggunakan gliserol sebagai plasticizer, sehingga dapat diketahui pengaruh dari penambahan kitosan dan gliserol terhadap kualitas plastik biodegradable. Metode yang digunakan pada penelitian ini adalah metode kuantitatif yang meliputi analisis kuat tarik dan elongasi serta analisis biodegradabilitas sedangkan analisis kualitatif produk meliputi analisis gugus termal dan analisi gugus fungsi. Konsentrasi gliserol yang digunakan adalah $1,5 \mathrm{ml} ; 2,5 \mathrm{ml} ; 3,5 \mathrm{ml}$ dan 4,5 $\mathrm{ml}$ dan konsentrasi kitosan $0,35 \mathrm{~g} ; 0,45 \mathrm{~g} ; 0,55 \mathrm{~g}$ dan $0,65 \mathrm{~g}$. Hasil dari penelitian ini menunjukkan nilai kuat tarik sebesar $21.20 \mathrm{Mpa}$; nilai elongasi sebesar 11,76\%; sedangkan nilai permeabilitas oksigen berkisar antara $4,82 \times 10^{-6}$ sampai dengan $2,66 \times 10^{-5}$ (Barrier); nilai penyerapan air berada pada nilai $58,37 \%$. Proses biodegradasi di dalam tanah yang mengandung bakteri EM4 dapat terurai habis selama 18 hari.
\end{abstract}

\begin{abstract}
Tapioca starch, also known as tapioca flour is produced from cassava tubers extract. It can be used as a main ingredient in the manufacture of biodegradable plastics. The purpose of this research was to create biodegradable plastic from tapioca starch and chitosan by using glycerol as plasticizer, with the aim of finding out the influence of chitosan and glycerol addition to the quality of biodegradable plastic. The method employed in this research was a quantitative method consisting of strength and elongation analyses and biodegradability analysis while a qualitative analysis of product encompasses the analyses of thermal and functional groups. The concentrations of glycerol used were $1.5 \mathrm{ml} ; 2.5 \mathrm{ml} ; 3.5 \mathrm{ml}$ and $4.5 \mathrm{ml}$ and the concentration of chitosan used were $0.35 \mathrm{~g} ; 0.45 \mathrm{~g} ; 0.55 \mathrm{~g}$ and $0.65 \mathrm{~g}$. The results of this research showed that the tensile strength value of $21.20 \mathrm{MPa}$; the elongation value of $11.76 \%$; the value of oxygen permeability was about $4.82 \times 10^{-16}$ to $2.66 \times 10^{-15}$ (Barrier); the value of water absorption was at $58.37 \%$. The biodegradation process in the soil containing EM4 bacteria can be completely decomposed for 18 days.
\end{abstract}

(C) 2020 Penulis. Dipublikasikan oleh Baristand Industri Padang. Akses terbuka dibawah lisensi CC BY-NC-SA

\section{Pendahuluan}

Jenis kemasan plastik banyak digunakan dalam berbagai keperluan, baik kebutuhan rumah tangga maupun kebutuhan industri. Tujuan penggunaan kemasan plastik untuk memberi perlindungan terhadap produk yang dikemas (Hendra et al., 2015). Akan tetapi sifat dari kemasan plastik yang sulit terurai secara biologis sehingga mengakibatkan penumpukan sampah dan pencemaran lingkungan (Astuti, 2018). Oleh karena 
itu dibutuhkan suatu kemasan yang biodegradable, yaitu kemasan yang mampu didaur ulang secara alami oleh mikroba dalam tanah dan hanya menghasilkan senyawa berupa karbondioksida, air, gas methane, serta cell biomass.

Sumber daya alam dari hasil pertanian dapat dimanfaatkan sebagai bahan baku pembuatan plastik biodegradable diantaranya: beras, jagung, kentang, gandum dan lainnya. Pati kulit singkong menjadi alternatif sebagai bahan utama dalam pembuatan plastik biodegradable. Hal tersebut disebabkan pati kulit singkong mudah didapat dan harganya terjangkau (Amni et al., 2015). Penggunaan pati sebagai bahan dasar pembuatan plastik biodegradable merupakan alternatif yang baik, dikarenakan pati merupakan salah satu jenis polisakarida dari tanaman yang tersedia melimpah di alam yang bersifat mudah terurai (biodegradable), mudah diperoleh, dan murah (Winarti et al., 2013).

Sebagai alternatif, pengembangan plastik yang bersifat biodegradable menjadi fokus pemerhati pengemasan bahan makanan. Dengan sifat biodegradable plastik diharapkan akan terurai di lingkungan dalam waktu singkat karena adanya kelembaban dan mikroorganisme. Pada penelitian sebelumnya telah dilakukan uji terhadap sifat mekanik, daya serap air dan uji biodegradable (Safitri et al., 2016).

Berdasarkan uraian diatas maka penelitian ini bertujuan untuk membuat plastik biodegradable berbahan dasar pati dari kulit singkong yang merupakan limbah dari proses pengolahan singkong. Variasi Penambahan kitosan sebagai penguat dan variasi penambahan gliserol sebagai plasticizer bertujuan untuk mendapatkan komposisi optimal plastik biodegradable terhadap permeabilitas oksigen. Metode yang digunakan pada penelitian ini adalah metode kuantitatif yang meliputi analisis kuat tarik dan elongasi serta analisis biodegradablitas sedangkan analisis kualitatif produk meliputi analisis gugus termal dan analisi gugus fungsi.

\section{Metode}

Bahan yang digunakan pada penelitian adalah tapioka, kitosan, gliserol, aquadest, asam asetat $2 \%$, $\mathrm{NaOH}$, alkohol dan bakteri EM4. Alat yang digunakan pada penelitian ini adalah beaker glass, pelat kaca, batang pengaduk, Erlenmeyer, thermometer, timbangan, autograph (Shimadzu $1000 \mathrm{G}$, Jepang) untuk uji mekanik, uji morfologi menggunakan SEM (JEOL JSM6701F, Jepang) di Fakultas Teknik Jurusan Teknik Mesin, uji termal menggunakan DSC (Mettler Toledo, Swiss) di Fakultas Teknik Jurusan Teknik Kimia, uji gugus fungsional menggunakan FTIR (Agilent Technologies Cary 630 merk Merck, Germany) di Laboratorium Kimia Fakultas MIPA, Oxygen Permeabilitas Tester di Jurusan Teknologi Hasil Pertanian Fakultas Pertanian Universitas Syiah Kuala dan cawan petri digunakan untuk uji biodegradabilitas.

Penelitian ini terdiri atas dua variabel yang terdiri dari empat taraf kosentrasi. Variabel utama adalah kosentrasi kitosan $(0,35 \mathrm{~g} ; 0,45 \mathrm{~g} ; 0,55 \mathrm{~g}$ dan $0,65 \mathrm{~g})$ dan variabel kedua kosentrasi gliserol $(1,5 \mathrm{ml} ; 2,5 \mathrm{ml} ; 3,5 \mathrm{ml}$ dan 4,5 ml).

\subsection{Pembuatan plastik biodegradable}

Dalam proses pembuatan plastik biodegradable didasarkan prinsip termodinamika, dimana keadaan awal larutan stabil kemudian mengalami ketidakstabilan pada proses perubahan fasa, proses pemadatannya (solidifikasi) diawali dari fasa cair menjadi padat. Pembuatan plastik biodegradable dilakukan dengan dua tahap, pertama melarutkan kitosan ke dalam larutan asam asetat $2 \%$ dengan menggunakan magnetic stirrer selama 1 jam. Larutan kitosan disaring, pengadukan larutan yang dihasilkan berwarna putih bening dan terdapat gelembung-gelembung udara yang terbentuk akibat pengadukan. Tahap kedua, pati yang telah dilarutkan dengan air ditambahkan larutan kitosan, kemudian campuran tersebut ditambahkan gliserol yang berfungsi sebagai plasticizer. Campuran tersebut dipanaskan sambil diaduk dengan menggunakan hot plate dan magnetic stirrer pada suhu $70^{\circ} \mathrm{C}$. Plastik tersebut dicetak di atas cetakan yang berbahan dasar polietilen, kemudian dikeringkan pada suhu ruang selama 24 jam.

\subsection{Analisis plastik biodegradable}

Plastik biodegradable yang dihasilkan diuji sifat mekanik seperti kuat tarik dan elongasi dengan menggunakan alat autograph. Uji gugus fungsional bertujuan untuk mengetahui gugus fungsi yang ada pada plastik biodegradable dengan menggunakan alat Fourier Transform Infra-Red (FTIR) tipe Agilent Technologies Cary 630 merk Merck Germany. Uji morfologi untuk mempelajari struktur permukaan, dimana material diamati dengan Scanning Electron Microscope (SEM) type JSM-6701F merek JEOL. Uji penyerapan air dilakukan untuk mengetahui seberapa banyak jumlah air yang mampu diserap oleh plastik biodegradable yang telah dibuat dalam selang waktu tertentu.

Uji permeabilitas oksigen dilakukan untuk mengetahui kemampuan plastik biodegradable melewatkan partikel gas pada suatu unit luasan bahan pada kondisi tertentu (Akbar et al., 2013). Nilai permeabilitas oksigen pada plastik biodegradable berguna untuk memperkirakan daya simpan produk. Uji biodegrabilitas bertujuan untuk mengetahui berapa lama waktu yang diperlukan oleh plastik biodegradable dapat terurai di dalam tanah yang mengandung bakteri EM4 dan menggunakan larutan $\mathrm{NaOH} 0,1 \mathrm{M}$.

\section{Hasil dan pembahasan}

\subsection{Kuat tarik (tensile strength)}

Pengukuran uji mekanik dilakukan terhadap plastik biodegradable dengan variasi komposisi kitosan dan gliserol, menggunakan alat autograph.

Pengukuran ini meliputi kuat tarik (tensile strength) dan persen pemanjangan saat putus (elongation to break) yang bertujuan untuk mengetahui besarnya gaya maksimum sebelum plastik biodegradable sobek/putus. Konsentrasi dan jenis bahan pembuat plastik biodegradable menentukan sifat kuat tarik (Amni et al., 2015). 


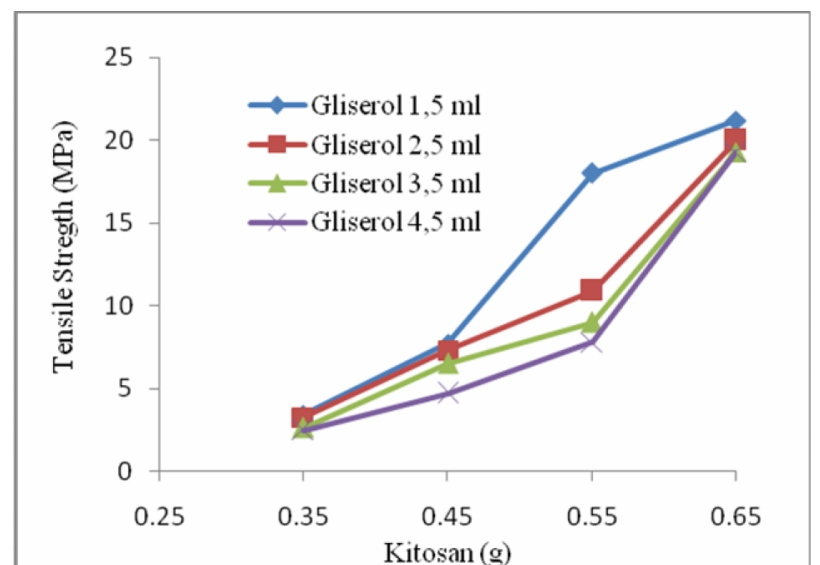

Gambar 1. Pengaruh konsentrasi kitosan dan gliserol terhadap kuat tarik (tensile strength) plastik biodegradable.

Gambar 1 memperlihatkan pengaruh konsentrasi kitosan dan gliserol yang berbeda terhadap hasil tensile strength plastik biodegradable, dimana pada grafik dapat dilihat bahwa penambahan konsentrasi kitosan dari 0,35 $\mathrm{g}$ sampai dengan 0,65 g nilai kuat tarik cenderung mengalami peningkatan, sedangkan dengan penambahan konsentrasi gliserol dari 1,5 ml sampai dengan 4,5 ml cenderung mengalami penurunan terhadap nilai kuat tarik pada plastik biodegradable yang dihasilkan.

Menurut (Widyaningsih et al., 2012) bahwa kitosan ditambahkan ke dalam matriks dengan tujuan meningkatkan sifat-sifat mekanik plastik melalui penyebaran tekanan yang efektif di antara serat dan matriks. Sedangkan penambahan gliserol dapat mengurangi nilai tensile strength. Nilai tensile strength plastik biodegradable yang dihasilkan pada penilitian ini berkisar 2,46 sampai dengan 21,20 Mpa.

Penelitian lain yang dilakukan oleh (Hartatik et al., 2014), bahwa semakin banyak kitosan yang ditambahkan maka dapat menurunkan nilai kuat tarik bioplastik sehingga menjadi rapuh. Selain itu pemanasan juga berpengaruh terhadap nilai kuat tarik bioplastik, dikarenakan dapat mengurangi kandungan air pada bioplastik sehingga struktur molekul semakin rapat dan homogen yang dapat meningkatkan nilai kuat tarik.

\subsection{Elongation of break}

Elongasi merupakan perpanjangan saat putus (elongation of break). Perpanjangan disebut dengan persentase perubahan panjang plastik pada saat ditarik sampai putus (Safitri et al., 2016). Gambar 2 memperlihatkan pengaruh konsentrasi kitosan dan gliserol yang berbeda terhadap persen elongasi plastik biodegradable dengan menggunakan jenis grafik scatter yang menunjukkan bahwa semakin tinggi konsentrasi gliserol yang ditambahkan maka nilai persen elongasi plastik biodegradable semakin tinggi. Dari Gambar 2 dapat dilihat bahwa pengaruh penambahan konsentrasi kitosan dari $0,35 \mathrm{~g}$ sampai dengan $0,65 \mathrm{~g}$ cenderung mengalami penurunan terhadap persen elongasi plastik biodegradable, sedangkan dengan penambahan konsentrasi gliserol dari 1,5 ml sampai dengan 4,5 ml nilai persen elongasi plastik biodegradable cenderung mengalami peningkatan. Hal yang sama dilakukan pada penelitian (Arini et el., 2017) menyatakan bahwa semakin tinggi kadar konsentrasi gliserol sehingga meninggkatnya nilai persen elongasi. Hal ini disebabkan gliserol mempunyai titik didih tinggi yang menyebabkan menurunnya gaya intermolekul antar rantai sehingga gerakan rantai lebih bebas yang menyebabkan fleksibilitas meningkat.

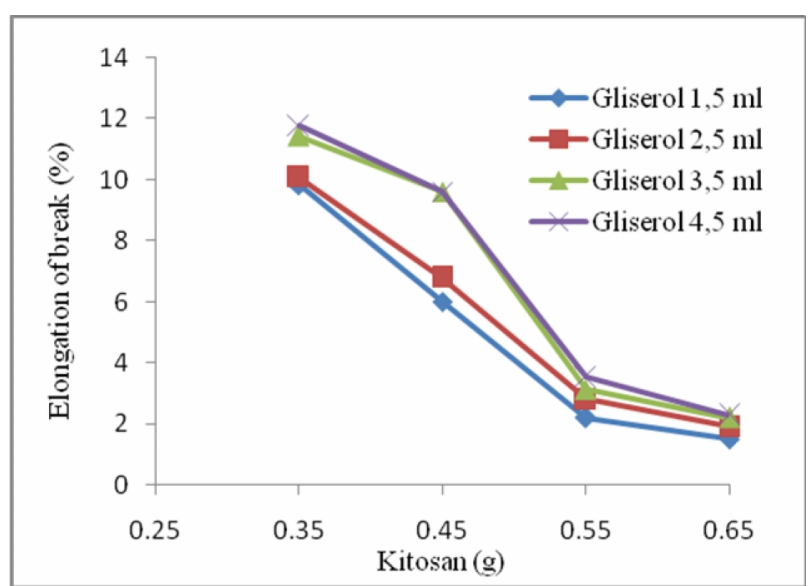

Gambar 2. Pengaruh konsentrasi kitosan dan gliserol terhadap persen elongasi plastik biodegradable.

Plasticizer juga mampu mengurangi kerapuhan dan meningkatkan fleksibilitas film polimer dengan cara mengganggu ikatan hidrogen antara molekul polimer yang berdekatan sehingga kekuatan tarik-menarik intermolekul rantai polimer menjadi berkurang (Widyaningsih et al., 2012). Konsentrasi gliserol yang ditambahkan dapat meningkatkan elastisitas plastik biodegradable yang dihasilkan. Hal ini disebabkan dengan menurunnya jarak ikatan intermolekuler pada plastik biodegradable (Safitri et al., 2016). Nilai elongasi plastik biodegradable yang dihasilkan pada penelitian ini berkisar 1,50\% sampai dengan $11,76 \%$.

\subsection{Analisis morfologi}

Pengamatan morfologi plastik biodegradable dilihat dengan menggunakan mikroskop elektron (Scanning Elektron Microscope, SEM). Sampel ditempelkan di atas tempat contoh dengan menggunakan perekat elektrokonduktif. Gambar difoto setelah mendapatkan gambar yang cukup jelas. Analisis ini bertujuan untuk menjelaskan bagaimana morfologi dari plastik biodegradable yang dihasilkan. Berdasarkan hasil uji menggunakan SEM dengan komposisi variabel kitosangliserol.

Hasil SEM plastik biodegradable dengan komposisi tepung pati tapioka dan kitosan dengan penambahan gliserol sebagai plasticizer dengan perbesaran 500×, pada Gambar 3(a) dengan penambahan kitosan 0,35 g terlihat banyak terdapat rongga, sedangkan pada Gambar 3(b) dengan penambahan konsentrasi kitosan 0,65 g terlihat bahwa rongga pada pada plastik biodegradable lebih rapat, hal ini disebabkan dengan adanya penambahan kitosan yang berfungsi sebagai penguat sehingga sulit ditembus oleh gas dan dapat meningkatkan nilai tensile strength. (Hartatik et al., 2014) menambahkan semakin tinggi konsentrasi kitosan yang ditambahkan maka semakin sedikitnya rongga pada 
bioplastik. Hal ini disebabkan struktur molekul pada bioplastik semakin rapat dan homogen. Sedangkan meningkatnya konsentrasi gliserol, maka rongga pada permukaan plastik biodegradable semakin membesar sehingga menyebabkan mudah rapuh (Coniwanti et al., 2014).

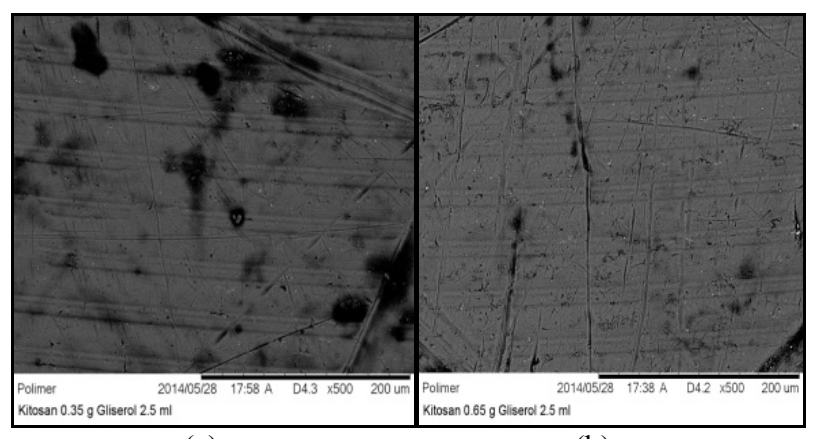

(a)

(b)

Gambar 3. Pengaruh konsentrasi kitosan dan gliserol terhadap morfologi plastik biodegradable

\subsection{Analisis permeabilitas oksigen}

Permeabilitas oksigen pada plastik biodegradable merupakan kemampuan partikel gas untuk melewatkan suatu unit luasan bahan pada kondisi tertentu. Pada Gambar 4 memperlihatkan pengaruh konsentrasi kitosan dan gliserol yang berbeda terhadap nilai permeabilitas oksingen pada plastik biodegradable dengan menggunakan jenis grafik scatter yang menunjukkan bahwa semakin tinggi konsentrasi gliserol yang ditambahkan maka nilai permeabilitas oksigen semakin meningkat, sedangkan semakin meningkatnya konsentrasi kitosan maka nilai permeabilitas oksigen semakin menurun.

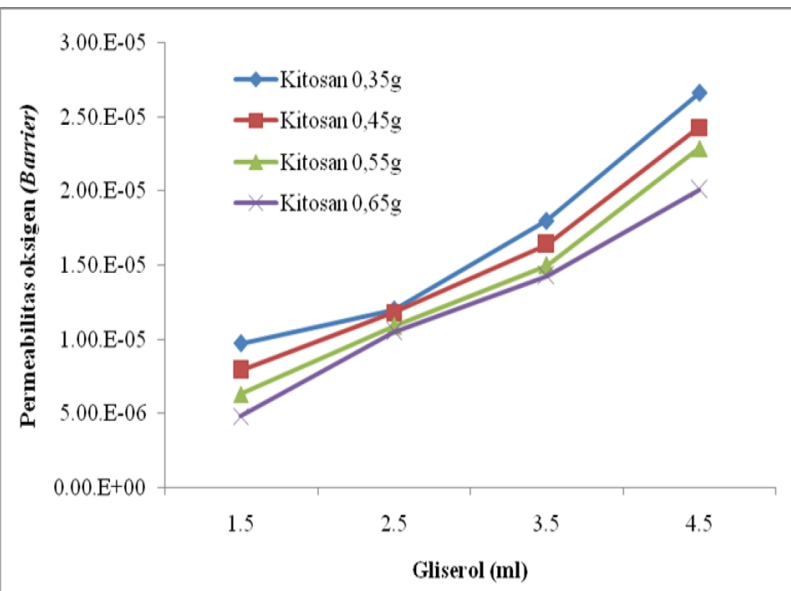

Gambar 4. Pengaruh konsentrasi kitosan dan gliserol terhadap permeabilitas oksigen pada plastik biodegradable.

Dari Gambar 4 dapat terlihat bahwa pengaruh penambahan konsentrasi gliserol dari 1,5 ml sampai dengan 4,5 $\mathrm{ml}$ cenderung mengalami peningkatan terhadap nilai permeabilitas oksigen plastik biodegradable, sedangkan dengan penambahan konsentrasi kitosan dari 0,35 g sampai dengan 0,65 g nilai permeabilitas oksigen plastik biodegradable cenderung mengalami penurunan.
(Safitri et al., 2016), menambahkan dengan meningkatnya konsentrasi gliserol dan menurunnya konsentrasi bahan pengisi, maka semakin tinggi nilai permeabilitas oksigen yang dihasilkan. Ketebalan plastik juga mempengaruhi permeabilitas oksigen, Nilai uji permeabilitas oksigen pada penelitian ini berkisar 4,82 $\mathrm{x}$ $10^{-6}-2,66 \times 10^{-5}$ (Barrier). Hal ini diduga dengan adanya penambahan kitosan maka pori-pori dari plastik biodegradable akan berkurang sehingga nilai permeabilitas semakin kecil.

\subsection{Analisis penyerapan air}

Uji penyerapan air dilakukan untuk mengetahui jumlah air yang mampu diserap oleh kemasan plastik biodegradable setelah perendaman dalam air selama selang waktu tertentu. Nilai persentase penyerapan air pada masing-masing plastik biodegradable dapat dilihat pada Gambar 5. Gambar 5 memperlihatkan pengaruh konsentrasi gliserol dan kitosan yang berbeda terhadap penyerapan air pada plastik biodegradable dengan menggunakan jenis grafik scatter yang menunjukkan bahwa semakin tinggi konsentrasi gliserol maka persen penyerapan air semakin meningkat, sedangkan semakin tinggi konsentrasi kitosan maka persen penyerapan air semakin menurun.

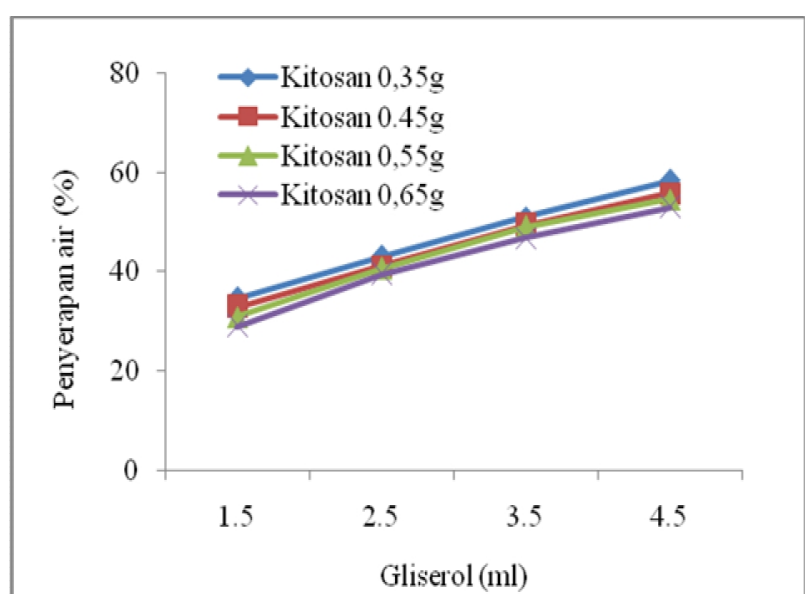

Gambar 5. Pengaruh konsentrasi gliserol dan kitosan terhadap penyerapan air pada plastik biodegradable.

Dari Gambar 5 dapat terlihat bahwa pengaruh penambahan konsentrasi kitosan dari $0,35 \mathrm{~g}$ sampai dengan 0,65 g cenderung mengalami penurunan terhadap persen penyerapan air pada plastik biodegradable, sedangkan dengan penambahan konsentrasi gliserol dari 1,5 ml sampai dengan 4,5 ml nilai persen penyerapan air pada plastik biodegradable cenderung mengalami peningkatan. Pada penelitian (Coniwanti et al., 2014) menyatakan hal yang sama bahwa semakin banyak konsentrasi kitosan maka kemampuan penyerapan air pada plastik biodegradable menurun, hal ini disebabkan kitosan memiliki sifat hidrofobik dan tak larut dalam air. Sedangkan penambahan gliserol dalam film pati akan menggangu properti hidrofobik permukaan film. Selain itu gliserol juga memiliki gugus hidroksil lebih banyak yang mempunyai sifat polar. Kapasitas penyerapan air juga dapat dihubungkan dengan struktur kimia bahan yang mempunyai gugus fungsional $(\mathrm{OH})$ yang dapat 
mengadsorbsi air. (Pramono et al., 2012) menambahkan bahwa keberadaan gugus hidrofil dalam suatu material mengakibatkan material tersebut mudah berinteraksi dengan air.

Sedangkan (Widyaningsih et al., 2012) menambahkan bahwa ketebalan film mempengaruhi kelarutannya artinya semakin tebal film maka semakin rendah daya larutnya karena kekompakan film sebagai akibat dari meningkatnya ikatan hidrogen seiring dengan meningkatnya ketebalan film. Ikatan hidrogen yang semakin meningkat mengakibatkan struktur molekul pati saling kuat berikatan membentuk jaringan yang kompak, sehingga menurunkan daya larut film. Nilai uji penyerapan air pada penelitian ini berkisar 29,03\%$58,37 \%$. Hal ini disebabkan karena kitosan bersifat hidrofobik dan tidak larut dalam air.

\subsection{Analisis gugus fungsi}

Film hasil pencampuran dijepit pada tempat sampel, kemudian diletakkan pada alat kearah sinar infra-red. Hasilnya akan direkam ke dalam kertas berskala berupa aliran kurva bilangan gelombang terhadap intensitas. Pada Gambar 6 dapat lihat hasil identifikasi gugus fungsi dengan menggunakan FTIR pada campuran pati, gliserol dan kitosan dengan panjang gelombang $\left(\mathrm{cm}^{-1}\right)$ 1645,35 terdapat ikatan rangkap dua seperti yang ditunjukkan pada simbol X, pada panjang gelombang $\left(\mathrm{cm}^{-1}\right) 2152,65$ terdapat vibrasi regang ikatan ganda sedangkan pada panjang gelombang $\left(\mathrm{cm}^{-1}\right) 3632,12$ terdapat gugus $\mathrm{OH}$.

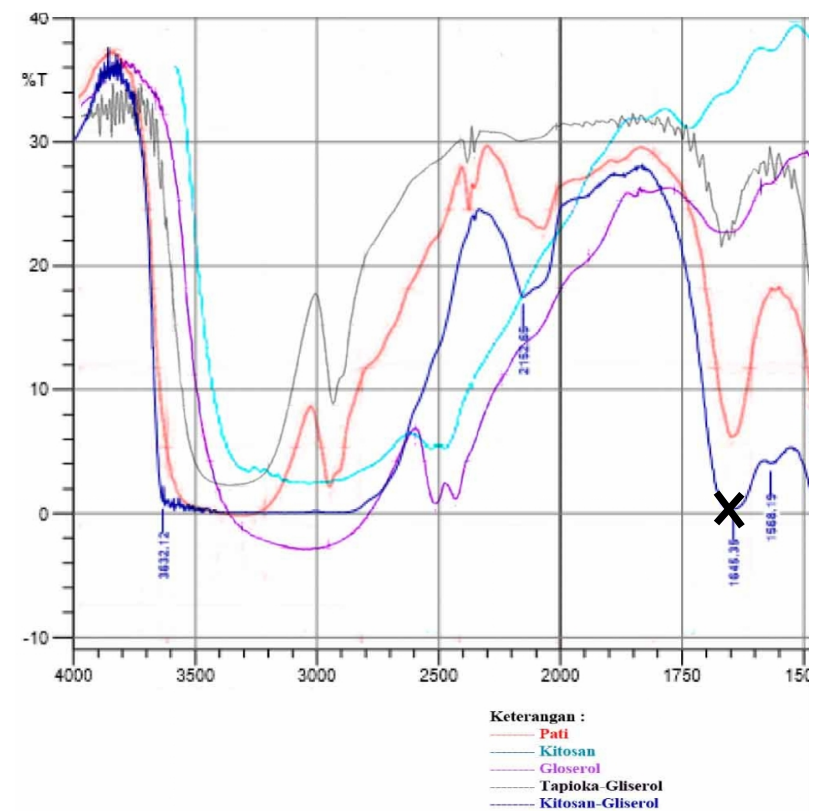

Gambar 6. Pengaruh konsentrasi kitosan dan gliserol terhadap gugus fungsi plastik biodegradable.

Pada penelitian sebelumnya (Akbar et al., 2013) mengatakan bahwa film plastik pati kulit singkong menunjukkan pola serapan pada daerah bilangan gelombang yang mirip dengan pati kulit singkong dimana terdapat gugus $\mathrm{C}-\mathrm{C}, \mathrm{C}=\mathrm{C}$ dan $\mathrm{OH}$. Hal ini berarti tidak ditemukannya gugus fungsi baru sehingga film plastik pati memiliki sifat-sifat seperti komponen penyusunannya.

\subsection{Analisis termal}

Pada Gambar 7 menunjukkan bahwa kenaikan suhu terjadi setiap penambahan konsentrasi kitosan, hal ini disebabkan karena semakin tinggi konsentrasi kitosan yang ditambahkan pada plastik biodegradable maka dapat meningkatkan ikatan hidrogen internal molekul dan menyebabkan meningkatnya intermolekul rantai polimer. Penambahan kitosan dapat meningkatkan ikatan hidrogen, sehingga dibutuhkan energi yang lebih besar dalam proses degradasinya (Pramono et al., 2012). Sedangkan suhu transisi gelas (Tg) sangat tergantung pada komposisi film dan kadar air, semakin fleksibel maka nilai $\mathrm{Tg}$ semakin rendah. Peningkatan kadar gliserol menurunkan temperatur transisi gelas $(\mathrm{Tg})$ karena matriks polimer menjadi kurang padat dan mobilitas rantai polimer difasilitasi dengan penambahan plasticizer, sedangkan semakin berat molekul dan panjang rantai maka semakin tinggi nilai Tg (Jimenez et all., 2013). Dimana temperatur tersebut bersifat glassy, dan di atas temperatur tersebut bersifat rubbery.

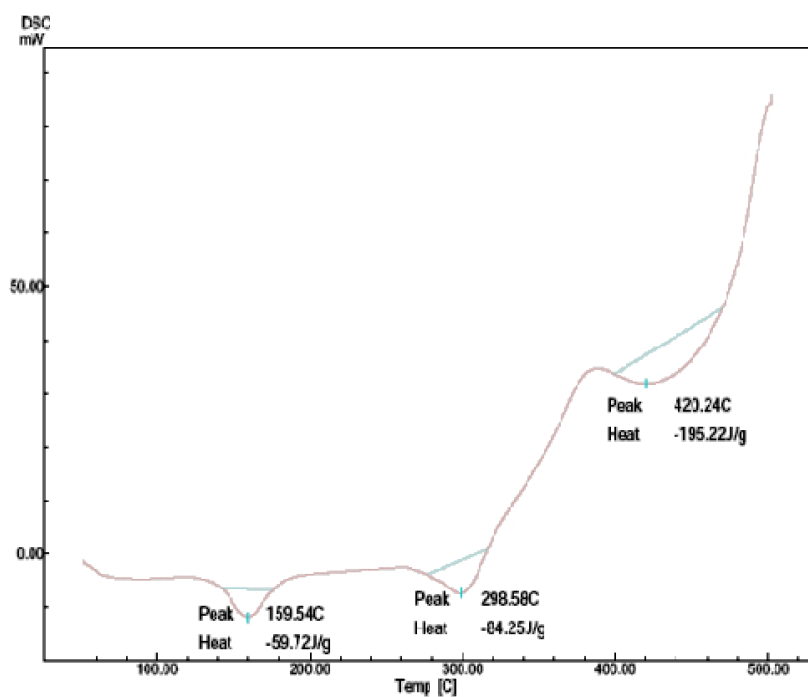

Gambar 7. Pengaruh konsentrasi kitosan dan gliserol terhadap uji termal.

\subsection{Degradasi menggunakan larutan $\mathrm{NaOH}$}

Gambar 8 memperlihatkan pengaruh konsentrasi kitosan dan gliserol yang berbeda terhadap persen kehilangan berat pada plastik biodegradable dengan menggunakan jenis grafik scatter yang menunjukkan bahwa semakin tinggi konsentrasi kitosan maka persen kehilangan berat plastik biodegradable semakin kecil, sedangkan semakin tinggi konsentrasi gliserol maka persen kehilangan berat plastik biodegradable semakin besar. Dari gambar 8 dapat terlihat bahwa pengaruh penambahan konsentrasi kitosan dari $0,35 \mathrm{~g}$ sampai dengan $0,65 \mathrm{~g}$ cenderung mengalami penurunan terhadap persen kehilangan berat plastik biodegradable, sedangkan dengan penambahan konsentrasi gliserol dari 1,5 ml sampai dengan 4,5 $\mathrm{ml}$ persen kehilangan berat plastik biodegradable cenderung mengalami peningkatan. 


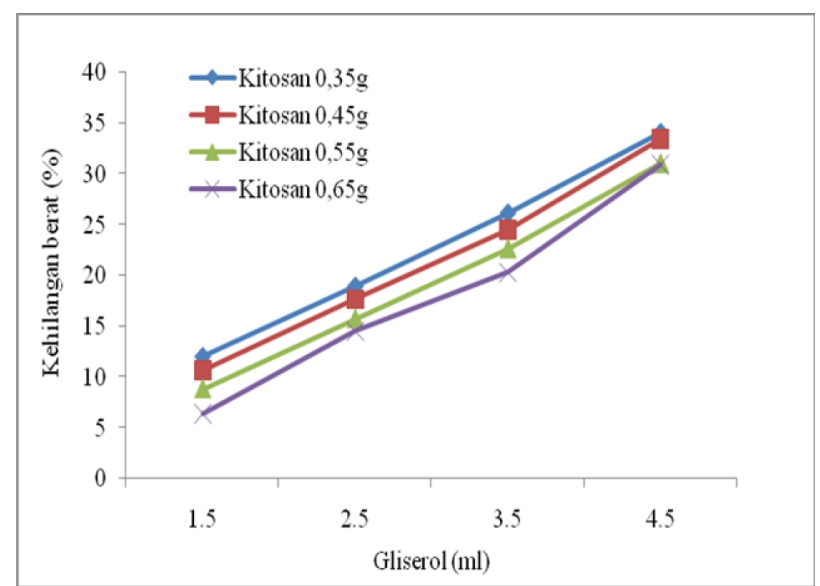

Gambar 8. Pengaruh konsentrasi kitosan dan gliserol terhadap biodegrabilitas plastik biodegradable di dalam larutan $\mathrm{NaOH}$.

Hal ini menunjukkan bahwa semakin besar hidrofilisitas pada plastik biodegradable, maka semakin besar tingkat terdegradasi. Hal ini karena plasticizer bersifat hidrofilisitas dan dengan adanya penambahan $\mathrm{NaOH}$ pada larutan pati, akan membentuk partikelpartikel yang akan masuk ke dalam struktur pati sehingga struktur akan merenggang membentuk rongga dan menyebabkan kehilangan berat plastik biodegradable meningkat. Riset yang dilakukan oleh (Coniwanti et al., 2014) menambahkan bahwa degradasi terjadi dengan cepat dengan meningkatnya konsentrasi gliserol yang ditambahkan, hal ini disebabkan gliserol mempunyai sifat hidrofilik yang mampu larut dengan mudah di dalam air.

\subsection{Analisis biodegradable di dalam tanah yang mengandung EM4}

Uji biodegradasi plastik biodegradable dilakukan dengan cara penguburan dalam media tanah mengandung bakteri EM4 (Effective Microorganism). EM4 adalah kultur campuran mikro yang terdiri dari bakteri Lactobacillus, Actinomyces, Streptomyces, ragi jamur dan bakteri fotosintesis yang bekerja saling menunjang dalam dekomposisi bahan organik.

Pengujian dilakukan pada semua sampel dilakukan setiap 3 hari sekali. Plastik biodegradable yang diuji dengan penguburan di dalam tanah yang mengandung bakteri EM4, habis terurai dalam waktu 18 hari yang ditunjukkan dengan rusaknya permukaan film plastik biodegradable. Dari hasil menunjukkan bahwa semakin banyak konsentrasi kitosan ditambahkan, maka semakin lama plastik biodegrable terdegradasi. Hal yang sama diungkapan oleh (Hartatik et al., 2014) bahwa penyebab lamanya bioplastik terdegradasi diakibatkan oleh banyaknya konsentrasi kitosan yang ditambahkan.

\section{Kesimpulan}

Berdasarkan hasil penelitian yang telah dilakukan maka dapat disimpulkan bahwa Daya permeabilitas $\mathrm{O}_{2}$ dipengaruhi oleh meningkatnya konsentrasi kitosan yang ditambahkan. Hasil uji spektrum FTIR identifikasi pada campuran pati, gliserol dan kitosan dengan bilangan gelombang 2152,65-3632,12 terdapat gugus $\mathrm{C}-\mathrm{H}, \mathrm{C}=\mathrm{C}$ dan $\mathrm{OH}$. Pada hasil analisis termal menunjukkan kenaikan titik leleh dengan adanya penambahan konsentrasi kitosan. Hasil uji biodegradabilitas menggunakan larutan $\mathrm{NaOH}$ ditentukan oleh meningkatnya konsentrasi gliserol, sedangkan hasil biodegradable dari pati tapioka dan kitosan dengan menggunakan gliserol sebagai plasticizer dapat terurai habis selama 18 hari dengan cara penguburan di dalam tanah yang mengandung bakteri EM4.

\section{Daftar pustaka}

Akbar, F., Anita, Z., \& Hamidah, H. 2013. Pengaruh waktu simpan film plastik biodegradasi dari pati kulit singkong terhadap sifat mekanikalnya. Jurnal Teknik Kimia USU, 2(2), 11-15.

Amni, C., Marwan, M., \& Mariana, M. 2015. Pembuatan bioplastik dari pati ubi kayu berpenguat nano serat jerami dan ZnO. Jurnal Litbang Industri, 5(2), 91.

Arini, D., Ulum, M. S., \& Kasman, K. 2017. Pembuatan dan pengujian sifat mekanik plastik biodegradable berbasis tepung biji durian. Natural Science: Journal of Science and Technology, 6(3), 276-283.

Astuti, A. D. 2018. Penerapan kantong plastik berbayar sebagai upaya mereduksi penggunaan kantong plastik. Jurnal Litbang: Media Informasi Penelitian, Pengembangan Dan IPTEK, 12(1), 32-40.

Coniwanti, P., Laila, L., \& Alfira, M. R. 2014. Pembuatan film plastik biodegredabel dari pati jagung dengan penambahan kitosan dan pemplastis gliserol. Jurnal Teknik Kimia, 20(4), 22-30.

Hartatik, Y. D., Nuriyah, L., \& Iswarin. 2014. Pengaruh komposisi kitosan terhadap sifat mekanik dan biodegradable bioplastik. Jurnal Penelitian, 5(10), 3 6.

Hendra, A. A., Utomo, A. R., \& Setijawati, E. 2015. Kajian karakterisitik edible film dari tapioka dan gelatin dengan perlakuan penambahan gliserol. Jurnal Teknologi Pangan Dan Gizi, 14(2), 95-100.

Jimenez, A., Fabra, M. J., Talens, P., \& Chiralt, A. 2013. Phase transitions in starch based films containing fatty acids. Effect on water sorption and mechanical behaviour. Food Hydrocolloids, 30(1), 408-418.

Pramono, E., Probowo, P. S. A., Purnawan, C., \& Wulansari, J. 2012. Pembuatan dan karakterisasi kitosam vanilin sebagai membran polimer elektrolit. Alchemy Jurnal Penelitian Kimia, 8(1), 70-78.

Safitri, I., Riza, M., \& Syaubari, S. 2016. Uji mekanik plastik biodegradable dari pati sagu dan grafting poly(Nipam)-kitosan dengan penambahan minyak kayu manis (Cinnamomum burmannii) sebagai antioksidan. Jurnal Litbang Industri, 6(2), 107.

Widyaningsih, S., Kartika, D., \& Tri Nurhayati, Y. 2012. Pengaruh penambahan sorbitol dan kalsium karbonat terhadap karakteristik dan sifat biodegradasi film dari pati kulit pisang. Molekul, 7(1), 69.

Winarti, C., Miskiyah, M., \& Widaningrum, W. 2013. Teknologi produksi dan aplikasi pengemas edible antimikroba berbasis pati. Jurnal Litbang Pertanian, 31(3). 